DOI https://doi.org/10.18551/rjoas.2020-11.27

\title{
COHERENCY OF TRANSFORMATIONAL LEADERSHIP, WORK WELFARE AND EMPLOYEE CREATIVITY
}

\author{
Juniarta Kadek Handi, Riana I Gede Surya ${ }^{*}$, Ida Bagus Ketut \\ Master's Program of Management, Faculty of Economics and Business, Udayana University, \\ Indonesia \\ *E-mail: gederiana@unud.aac.id
}

\begin{abstract}
Employee creativity is the ability of employees to create something different both in the form of assessable results and ideas. Creativity is said to be an action that produces new and different creations. The employee creativity can maximize the achievement of organizational goals. Human resources (HR) are the main asset of the organization; therefore, the employees are expected to have high creativity. The purpose of this study is to analyze the effect of transformational leadership and work welfare on employee creativity. The study was conducted in some guest houses and restaurants in Ubud, with the sample of 93 employees. Furthermore, the collected data were analyzed using Structural Equation Modeling (SEM) by applying WarpPLS approach. The results of the study show that transformational leadership has a positive and significant effect on employee creativity. Meanwhile, work welfare has a positive and significant effect on employee creativity. The implication of this research shows that, to increase employee creativity, organizations can provide lessons about the importance of transformational leader values. In addition, creating creative employees can be done through good work welfare. The study also shows that increasing employee creativity can be conducted by sharing the necessity of creativity in an organization, in addition to the need of transformational leadership values.
\end{abstract}

\section{KEY WORDS}

Employee creativity, transformational leadership, work welfare.

The era of globalization, which is characterized by the existence of a dynamic labor market, keeps a number of advantageous employees and spurs every employee to be creative as much as possible. As the basis of an organizational innovation, it is important to motivate some potential employees and trigger each employee to unleash their creativity, which is the key to achieve an organizational transformation (Liu \& Chen, 2011). Employee creativity is the generation of new ideas and is useful as a foundation for innovation in an organization. Therefore, increasing employee creativity effectively has become one of the goals of the organization (Liu et al., 2017). The components that affect employee's creativity consist of internal factors and external factors (Mustika, 2017). These internal factors are embedded in the employees themselves, namely cognitive style and personality. Meanwhile, external factors come from outside influences, namely support from leaders, support from colleagues and job characteristics.

Leadership is a process by which an individual influences a group of individuals to achieve common goals (Bishop, 2013). Transformational leadership is a leadership style that inspires followers to engage, commit, and share their visions and goals for the organization (Indrayanto et al. 2014). A leader with the transformational leadership inspires the employees to give more effort and dedication to obtain what their organization needs (Ribeiro et al., 2018). According to Cavazotte et al. (2012), the leaders with transformational leadership have an intelligence and personality to influence their employees directly or indirectly through a good communication. In addition, Robbins \& Judge (2015) state that transformational leadership is a leader who inspires his followers to put their personal interests aside as they must be professional in their organization and is able to bring a tremendous influence on the employees. That leader pays attention to the self-development needs of the employees, changes employees' awareness of some existing issues by helping others to see the 
previous problems in new ways, and is able to please and inspire the employees to work hard to achieve the common goals. In an increasingly competitive business environment, work welfare is a positive psychological condition for all employees in an organization, gradually becoming one of the key factors in influencing the level of employee creativity which will have an impact on the organization's competitive advantage. Therefore, the management of the organization takes an effective way in helping employees to improve their work welfare. When these conditions are resolved, the work welfare of good employees will have an impact on the creativity of the employees in an organization. According to the research conducted by Miao and Cao (2019), the work welfare has a positive effect on employee creativity.

There are variables related to the work welfare, especially creativity, which can predict employee welfare at the same time, specifically in the psychological aspect (Kazemi \& Ghorbani, 2015). Some weaknesses in the organization are more likely to have a negative impact on employees with low work welfare than those with high work welfare. The employees with high work welfare will expand information processing strategies and explore their cognitive potential, which will help them to increase creative initiative and motivation to deal with problems (Miao \& Cao, 2019). This is in line with the studies conducted by Egwakhe \& Umukoro (2019), Helzer \& Kim (2016) and Jain \& Jain (2016) which state that the work welfare positively affects employee creativity. Leadership is an important contextual factor in the workplace and will no doubt have a significant impact on employee creativity. The transformational leadership influences the creativity of employees, this means that the characteristics of a leader's behavior can result in employee creativity. This research is reinforced by the statement of Cheung and Wong (2011) which states that the transformational leadership is positively related to employee creativity. This is also supported by the studies of Gumusluoglu and Ilsev (2009), Henkeret et al. (2014), Gonget et al. (2009), as well as Wanget et al. (2014), which state that the employee creativity is influenced positively by the transformational leadership; furthermore, the transformational leadership also positively promotes an employee self-efficacy, as the transformational leader gives a verbal persuasion and psychological arousal to develop employee self-efficacy (Bass and Avolio, 1992). Based on the statements above, this study aims to analyze the effect of transformational leadership on employee creativity, to analyze the effect of work welfare on employee creativity.

\section{LITERATURE REVIEW}

Employees are the most important and vital resource for all organizations because they are an investment, asset and source of competitive advantage for businesses and organizations. The employee creativity is the generation of new ideas and is useful as a foundation for innovation in an organization. Therefore, effectively improving the employee creativity has become one of the goals of every organization (Liu et al., 2017). Furthermore, transformational leadership is a leadership style that inspires followers to engage, commit, and share their visions and goals for the organization (Indrayanto et al. 2014). Among the various leadership styles, the transformational leadership is a well-known and effective leadership style that plays an important role in the research of employee creativity. Bass (1985) argues that transformational leadership is a four-dimensional concept, including charisma or idealized influence, inspirational motivation, individual consideration, and intellectual stimulation. According to Mittal and Dhar (2015), the transformational leadership inspires the employees to give more efforts for the improvement of the organization (Ribeiro et al., 2018). According to Cavazotte et al. (2012) transformational leaders have intelligence and personality which gives a direct or indirect influence to the employees through their communication ability.

Yukl (2009), mentioned that transformational leadership changes the personal values of subordinates to support the visions and goals of the organization by maintaining the environment where relationships can be formed and by building a climate of trust in which visions can be shared. The basic assumption of the transformational leadership is that 
everyone will follow someone who can provide inspiration, has a clear vision, and has good energy to achieve something big (Syaifuddin, 2016). In an increasingly competitive business environment, work welfare is a positive psychological condition for all employees in an organization, which gradually becomes one of the key factors in influencing the level of employee creativity which will later have an impact on organizational competitive advantage. Leaders are one of the factors for increasing employee creativity, of which the leaders who are able to inspire and motivate employees to achieve the goals that are more precise than what are planned is called as transformational leadership (Gibson et al., 1997). The work welfare is present when the employees realize their potential, are resilient in facing the normal pressures of their lives, maintain their physical well-being and have a sense of achieving goals, connections, and more (Tov, 2018). Ahmed et al. (2018) state that the work welfare explains the level of balance between the groups of workers' resources and challenges such as the demands they face. Therefore, every time the challenge of the resources they have to reduce the pressure demand for problems with work welfare can be greater. As an important research topic on positive psychology, the work well-being refers to job-related satisfaction, work-related tension, and work-related depression. Current research on work well-being mostly contains two philosophical orientations, one is a hedonic approach that expresses emotional expression and a eudaimonic approach that reflects the meaning of work, work values, and personal development (Bakker et al., 2012). A way to effectively help employees improve employee creativity has become a management problem that organizations need to solve (Bakker et al., 2010). Currently, there are two competing perspectives on the impact of high-performance work systems on employee welfare, namely the unitary perspective and the pluralist perspective.

Zhou and Shalley (2008) clarify that some organizations suggest employees who have work welfare, a positive psychological state to stimulate employee creativity, are more likely to show their creativity if they are supported or assisted by the transformational leadership. Thus, based on the interactive point of creativity, when the transformational leadership is higher, the positive relationship between work welfare and employee creativity is stronger. Conversely, the employees who are influenced by a low-level transformational leadership will have doubt and confusion about the organization and the leader, and sometimes even begin to doubt the positive role of leadership in the organization because they do not see the care, support, and help of the leader. Gumusluoglu and Ilsev (2009) say that although employees have a feeling of work welfare, which can be seen as a prerequisite for stimulating employee creativity, the low-level transformational leadership makes employees ambiguous about the visions and goals of the organization, and at the same time, the employees also do not understand the moral, role and support of their leaders. Therefore, their sense of identification and commitment to the organization will gradually diminish and sometimes even make them begin to doubt their work motivation (Li and Shi, 2008). In this situation, the lowlevel transformational leadership will inhibit the positive impact of work welfare on employee creativity. In general, when the employees perceive a higher level of transformational leadership, the positive relationship between work welfare and employee creativity is stronger, so that work welfare will further transmit employee creativity. Conversely, when the employees perceive a lower level of transformational leadership, the positive relationship between work welfare and employee creativity becomes weaker. Several similar studies, such as Bono et al. (2007) have found that transformational superior leadership will strengthen a positive relationship between employee's work welfare and employee creativity. (Oreg \& Berson, 2011)

$\mathrm{H1}$ : Transformational leadership has a significant effect on employee creativity;

$\mathrm{H} 2$ : Work welfare has a significant effect on employee creativity.

\section{METHODS OF RESEARCH}

This research was conducted in guest houses and restaurants in Ubud Bali with a population of all employees of those industries which in total was 140 people. The samples were obtained using the technique of purposive sampling. The calculation result of the 
sample was 93 employees. The quantitative and qualitative data, both from primary and secondary sources, were collected by conducting interviews and distributing questionnaires. The questionnaires were compiled based on a number of question items, namely the employee creativity variable adopting Zhou and George's research (2001), the transformational leadership variable adopting Yukl's research (2010), the work welfare variable adopting the research of Zheng et al. (2015). Before the data was collected as a whole, the data quality was tested on the research instrument using 30 samples. The results of the data quality test show that the product moment correlation value is $\geq 0.30$ and the value of Cronbach alpha is $\geq 0.30$; thus, the research instrument is declared valid and reliable (Sugiyono, 2015) . Furthermore, the collected data were analyzed using descriptive analysis and inferential analysis of the WarpPLS software. Furthermore, the profiles of the research respondents are described in table 1, below.

Table 1 - Characteristics of Respondents

\begin{tabular}{|c|c|c|c|c|}
\hline No. & Information & Classification & Number of people) & Percentage (\%) \\
\hline \multirow[t]{4}{*}{1} & \multirow[t]{4}{*}{ Age } & $24-30$ years old & 55 & $55 \%$ \\
\hline & & 31 - 37 years old & 24 & $24 \%$ \\
\hline & & $38-44$ years old & 12 & $12 \%$ \\
\hline & & $>44$ years old & 2 & $2 \%$ \\
\hline \multirow[t]{2}{*}{2} & \multirow[t]{2}{*}{ Gender } & Male & 49 & 52.7 \\
\hline & & Women & 44 & 47.3 \\
\hline \multirow[t]{5}{*}{3} & \multirow[t]{5}{*}{ Education } & D1 & 18 & 19.4 \\
\hline & & $\mathrm{D} 2$ & 5 & 5,4 \\
\hline & & D3 & 27 & 29.0 \\
\hline & & S1 & 4 & 4,3 \\
\hline & & Vocational High School & 39 & 41.9 \\
\hline 4 & Years of service & $6-10$ years old & 93 & 100.0 \\
\hline 5 & Job status & Permanent & 93 & 100.0 \\
\hline \multirow[t]{9}{*}{6} & \multirow[t]{9}{*}{ Position } & Accounting \& General & 4 & 4,3 \\
\hline & & Engineering & 4 & 4,3 \\
\hline & & Finance & 6 & 6.5 \\
\hline & & Food and Beverage Product & 18 & 19.4 \\
\hline & & Food and Beverage Service & 20 & 21.5 \\
\hline & & Front Office & 7 & 7.5 \\
\hline & & Housekeeping & 21 & 22.6 \\
\hline & & Human Resources Development & 6 & 6.5 \\
\hline & & sales marketing & 7 & 7.5 \\
\hline
\end{tabular}

\section{RESULTS OF STUDY}

Discriminant Validity. Discriminant validity is conducted to ensure that each concept of each latent variable is different from other variables. The model is said to have good discriminant validity if every value of cross loading indicator of a latent variable is more substantial than the value of cross loading in correlation with the other variables of latent. The results for cross loading of the four variables are presented in Table 2 below.

Table 2 - Cross Loading Value

\begin{tabular}{llll}
\hline & Leadership Transformational & Well-being Work & Employee Creativity \\
\hline TL1 & 0.962 & 0.011 & -0.001 \\
\hline TL2 & 0.929 & -0.278 & 0.315 \\
\hline TL3 & 0.943 & -0.093 & 0.096 \\
\hline TL4 & 0.781 & 0.430 & -0.489 \\
\hline KK1 & 0.001 & 0847 & 0.217 \\
\hline KK2 & 0.042 & 0.865 & 0.006 \\
\hline KK3 & 0.089 & 0811 & -0.102 \\
\hline KK4 & -0.128 & 0841 & -0.131 \\
\hline KK5 & 0.060 & 0897 & 0.102 \\
\hline KK6 & -0.061 & 0.914 & -0.095 \\
\hline Kre1 & -0.063 & 0.237 & 0.921 \\
\hline Kre2 & -0.043 & -0.007 & 0.924 \\
\hline Kre3 & 0.095 & -0.121 & 0.949 \\
\hline Kre4 & 0.008 & -0.104 & 0.933 \\
\hline
\end{tabular}

Source: Data processed, 2020. 
The table 2 shows that the cross loading obtained by each latent variable is higher than the other latent variables; hence, it can be said that the latent variable has met discriminant validity. It can be seen that the correlation of employee creativity construct $(Y)$ is higher than work welfare $\left(X_{2}\right)$, and transformational leadership $\left(X_{1}\right)$.

Composite Reliability. Reliability measurement can be conducted using One Shot or a once-measurement. In this study, the measurement is only conducted once. Furthermore, the results are compared with the other questions or measure the correlation between the answers to the questions. The tool for measuring reliability is Cronbach Alpha. The reliability of a variable can be seen as follows (Ghozali, 2009: 49): Results $\alpha>0.70=$ reliable and Results $\alpha<0.70=$ not reliable.

Table 3 - Composite Reliability

\begin{tabular}{llll}
\hline Variable & Composite & Cronbach Alpha & Information \\
\hline Transformational Leadership (X1) & 0.948 & 0.925 & Reliable \\
\hline Work Welfare (X2) & 0.946 & 0.931 & Reliable \\
\hline Employee Creativity $(\mathrm{Y})$ & 0.964 & 0.949 & Reliable \\
\hline
\end{tabular}

Source: Data processed, 2020.

The table 3 shows that all research variables meet composite reliability because their values are above the recommended number, which is above 0.70 that has met the criteria of reliability. Based on the overall evaluation results, both are convergent. Furthermore, based on the discriminant validity and composite reliability, which has been described above, it can be concluded that all indicators to measure the latent variables are all valid and reliable; hence, further testing can be carried out.

Inner Model Evaluation. The inner model test or structural model is tested to see the relationship between variables, the significance of value and the R-square of the research model. The structural model is evaluated using the R-square for the dependent variable $t$ test as well as the significance of the structural path parameter coefficients. Model assessment with PLS is started by looking at the R-square for each dependent latent variable. Changes in the R-square value can be used to assess the effect of certain exogenous latent variables on endogenous latent variables that have a substantive effect. Table 4 shows the results of the R-square estimation using Smart PLS.

Table 4 - Value of R Square

\begin{tabular}{ccc}
\hline Variable & R Square & R Square Adjusted \\
\hline Employee & 0.696 & 0.690 \\
\hline Source: Data processed, 2020. & &
\end{tabular}

Table 4 shows the R-square value of the employee creativity variable of 0.696 . The higher R-square value, the greater the ability of the exogenous variable to be explained by endogenous variables, causing the better the structural equation. Employee creativity variable has an $\mathrm{R}$-square value of 0.696 , which means that $69.6 \%$ percent of employee creativity variance can be explained by work welfare and transformational leadership variables, while the rest is explained by other variables outside the research model.

Hypothesis Testing. The results of hypothesis testing with the Partial Least Square structural equation model are shown in Figure 1.

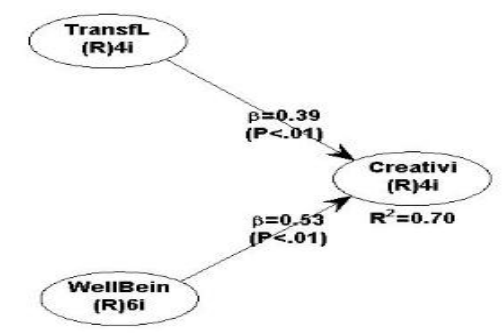

Figure 1 - WarpPLS analysis 
Table 5 - Path Coefficients

\begin{tabular}{lll}
\hline Variable & Total Effect & $\mathrm{P}$ Values \\
\hline Transformational Leadership $\left(\mathrm{X}_{1}\right) \rightarrow$ Employee Creativity $(\mathrm{Y})$ & 0.392 & 0.000 \\
Work Welfare $\left(\mathrm{X}_{2}\right) \rightarrow$ Employee Creativity $(\mathrm{Y})$ & 0.530 & 0.000 \\
\hline
\end{tabular}

Source: Data processed, 2020.

The Table 5 above shows that the results of hypothesis testing with the following discussion details.

Hypothesis 1 states that transformational leadership has a positive and significant effect on employee creativity. The result of the parameter coefficient test between transformational leadership and employee creativity shows that there is a positive relationship with the beta coefficient value of 0.392 with a $\mathrm{p}_{\text {value }}<0.05$; therefore, $\mathrm{Ho}$ is rejected and the research hypothesis is accepted. Thus, $\mathrm{H}_{1}$ is accepted. Furthermore, hypothesis 2 states that work welfare positively and significantly affects employee creativity. The test results parameter coefficient between work welfare for the creativity of employees showed a positive correlation with the value of the coefficient beta of 0.530 with $p_{\text {value }}<0.05$, which means that $\mathrm{Ho}$ is rejected and the research hypothesis is accepted. Hence, the $\mathrm{H}_{2}$ is accepted. The results of testing the hypothesis show that the two proposed hypotheses are accepted.

\section{DISCUSSION OF RESULTS}

Based on the results of the data analysis in Table 4, the transformational leadership is shown to have a positive and significant effect on employee creativity. This means that the higher the transformational leadership in an organization is, the better employee creativity will be. This is because among the leadership styles, the transformational leadership, which is an effective and well-known leadership style, plays an important role in creativity research. Bass (1985) states that transformational leadership is a four-dimensional concept, including charisma or idealized influence, inspirational motivation, individual consideration, intellectual stimulation.

This research is in line with the previous study conducted by Mittal and Dhar (2015) which explains that the transformational leadership affects employee creativity, this means that the characteristics of a leader's behavior can generate employee creativity. Another empirical evidence also explains that transformational leadership is positively related to employee creativity (Cheung and Wong, 2011), because a transformational leader provides verbal persuasion and psychological arousal to develop employee self-efficacy (Bass and Avolio, 1992). In an organization, a leader has a high commitment related to his duties and responsibilities that have an impact on employees; furthermore, the leadership also provides motivation to each employee who is willing to learn and develop their creativity. The existence of an inspirational leader is very important as he can motivate subordinates to increase every activity of the organization, pay attention to the career advancement of his subordinates, make each employee issue all his creative ideas that have an impact on the organization going forward. Thus, it can be concluded that this is in accordance with the hypothesis that transformational leaders have a positive and significant effect on employee creativity, so that the hypothesis is proven.

Based on the results of data analysis in Table 4, the work welfare has a positive and significant effect on employee creativity. This means that the higher the work welfare of employees in an organization is, the better employee creativity will be. This is in line with the statement that employees with high work welfare will also expand their information processing strategies and explore their cognitive potential, which will help them to increase creative initiative and motivation to deal with problems (Miao \& Cao, 2019). This study is also in accordance with the previous studies conducted by Egwakhe \& Umukoro (2019), Helzer \& Kim (2016) and Jain \& Jain (2016) which states that the work welfare has positively influenced the creativity of employees. Other empirical evidence also explain that variables 
related to work welfare, in particular the dimensions of creativity, can predict employee welfare, especially in the psychological aspects (Kazemi \& Ghorbani, 2015).

An organization will be predicated to have a good welfare of the it has made the employees satisfied with the responsibilities they carry out in the organization (in accordance with the provisions that make employees feel prosperous and have an impact on their desire for creativity). With the existing ideas in every employee's work which are received by the leaders, there will be a sense that every creativity is appreciated. The employee welfare can also be measured by the employees' achievements, the amount of experience they have can also increase their creativity. Thus, it can be concluded that this is in accordance with the hypothesis that work welfare has a positive and significant effect on employee creativity, so that the hypothesis is proven.

\section{CONCLUSION}

A leader must know his own strengths and weaknesses because it can affect his subordinates, including the factors of the employee's welfare as well as the employee's creativity. Some organizations that aspire to increase employee creativity must focus on selecting their leaders, in which the transformational leaders that have a good impact on the organization must be prioritized. Those organizations can support managers in achieving the more transformational style that can influence employee creativity. Transformational leadership has been shown to increase employee creativity. The stronger the transformational leadership value is, the higher employee creativity will be. Work welfare has also been proven to increase employee creativity. It means that with the more and higher work welfare that is perceived by the employee, the employee creativity will further increase.

\section{REFERENCES}

1. Ahmed, U., Mozammel, S., \& Ahmed, H. (2018). Performance on the road: examining the critical role of training effectiveness amongst the blue-collar employees in Bahrain. Asian Journal of Empirical Research, 8(9), 342-351.Bass, M. Bernard and Riggo, E. Ronald. 2006 . Kepemimpinan transformasional. Second Edition. New Jersey : Lawrence Erlbaum Associates, inc.

2. Bass, B. M., \& Avolio, B. J. (1993). Transformational leadership and organizational culture. Public administration quarterly, 112-121.

3. Bakker, A.B.; Bal, M.P. 2010. Weekly work engagement and performance: A study among starting teachers. J. Occup. Organ. Psychol. 83, 189-206.

4. Bishop, W. H. (2013). Defining the Authenticity in Authentic Leadership. The Journal of Values-Based Leadership, 6(1), 1-8.

5. Bono, J.E.; Foldes, H.J.; Vinson, G.; Muros, J.P. 2007. Workplace emotions: The role of supervision and leadership. J. Appl. Psychol. 92, 1357-1367.

6. Cavazotte, F., Moreno, V., \& Hickmann, M. (2012). Effects of leader intelligence, personality and emotional intelligence on transformational leadership and managerial performance. The Leadership Quarterly, 23(3), 443-455.

7. Chen, T. J., Lin, C. C., \& Wu, C. M. (2016). High performance work system, psychological efficacy, job satisfaction and task performance in the Hotel Workplace. Open Journal of Social Sciences, 4(7), 76-81.

8. Cheung, M. F., \& Wong, C. S. (2011). Transformational leadership, leader support, and employee creativity. Leadership \& Organization Development Journal.

9. Fan, D., Cui, L., Zhang, M. M., Zhu, C. J., Härtel, C. E., \& Nyland, C. (2014). Influence of high performance work systems on employee subjective well-being and job burnout: empirical evidence from the Chinese healthcare sector. The International Journal of Human Resource Management, 25(7), 931-950.

10. Ribeiro, L. S., Órfão, J. J. M., \& Pereira, M. F. R. (2018). Insights into the effect of the catalytic functions on selective production of ethylene glycol from lignocellulosic biomass over carbon supported ruthenium and tungsten catalysts. Bioresource technology, 263, 
402-409.

11. Robinson, J. A. G. (1989). The Montgomery bus boycott and the women who started it: The memoir of Jo Ann Gibson Robinson. Univ. of Tennessee Press.

12. Kazemi, S., Ghorbani, A., Amindavar, H., \& Morgan, D. R. (2015). Vital-sign extraction using bootstrap-based generalized warblet transform in heart and respiration monitoring radar system. IEEE Transactions on Instrumentation and Measurement, 65(2), 255-263.

13. Ghozali, I. (2009). Ekonometrika: Teori, Konsep, and Aplikasi dengan SPSS 17. Semarang: Badan Penerbit Universitas Diponegoro.

14. Gong, J., Wang, L., Song, D., Zhu, X., \& Zhang, L. (2009). Stripping voltammetric analysis of organophosphate pesticides using Ni/Al layered double hydroxides as solidphase extraction. Biosensors and Bioelectronics, 25(2), 493-496.

15. Gumusluoglu, L., \& Ilsev, A. (2009). Transformational leadership, creativity, and organizational innovation. Journal of business research, 62(4), 461-473.

16. Handoko, T. H. (2001). Manajemen personalia and sumber daya manusia, edisi kedua. Yogyakarta: BPFE.

17. Helzer, E. G., \& Kim, S. H. (2019). Creativity for workplace well-being. Academy of Management Perspectives, 33(2), 134-147.

18. Henker, N., Sonnentag, S., \& Unger, D. (2015). Transformational leadership and employee creativity: the mediating role of promotion focus and creative process engagement. Journal of Business and Psychology, 30(2), 235-247.

19. Indrayanto, A., Burger, J., Darayam, K., \& Noermijati. 2014. A Case Study of Transformational Leadership and Para-police Performance in Indonesia. Policing, an International Journal of Police Strategies \& Management, 37(2): 373-388

20. Johnson, E. A. (2014). Leadership dual behaviour and workers' performance: A peopletask orientation model. Journal 25: pp, 7, 23.

21. Jain, R., and Jain, C. 2016. Kreativitas karyawan: A Conceptual Framework. Management and Labour Studies, 41 (4), 294-313.

22. Liao, H., Toya, K., Lepak, D. P., \& Hong, Y. (2009). Do they see eye to eye? Management and employee perspectives of high-performance work systems and influence processes on service quality. Journal of applied psychology, 94(2), 371.

23. Liu, D., Chen, X. P., \& Yao, X. (2011). From autonomy to creativity: A multilevel investigation of the mediating role of harmonious passion. Journal of Applied Psychology, 96(2), 294.

24. Liu, D., Gong, Y., Zhou, J., \& Huang, J. C. (2017). Human resource systems, employee creativity, and firm innovation: The moderating role of firm ownership. Academy of Management Journal, 60(3), 1164-1188.

25. Li, C.; Shi, K. 2008. The structure and measurement of transformational leadership in China. Front. Bus Res China. 2, 571-590.

26. Miao, R., \& Cao, Y. (2019). High-performance work system, work well-being, and employee creativity: Cross-level moderating role of transformational leadership. International journal of environmental research and public health, 16(9), 1640.

27. Miao, R., Zhou, W., Xie, B., \& Wang, B. (2014). High-performance Work system, Psychological Capital and Employee Attitudes£ ${ }^{\circ} \mathrm{A}$ Chinese Study. In Academy of Management Proceedings (Vol. 2014, No. 1, p. 14955). Briarcliff Manor, NY 10510: Academy of Management.

28. Miao, R., \& Cao, Y. (2019). High-performance work system, kesejahteraan kerja, and kreativitas karyawan: Cross-level moderating role of transformational leadership. International Journal of Environmental Research and Public Health. 16 (9), 1-24.

29. Mittal, Swati and Rajib, Lochan. Dhar. (2015). Transformational Leadership and Employees Creativity as a Mediator Roles of Efikasi diri kreatif and Moderating Roles of Knowledge Sharing. Management Decisions. 53 (5), 894-910.

30. Mustika, M. S. (2017). Pengaruh Kepribadian Proaktif pada Kreativitas Karyawan dengan Kepemimpinan Transformasional and Autonomi Kerja sebagai Variabel Pemoderasi. Jurnal Bisnis Darmajaya, 3(2), 126-145..

31. Robbins, S. P., \& Judge, T. A. (2015). Organizational Behavior. Pearson. 
32. Sugiyono, P. D. (2015). Metode Penelitian Bisnis: Pendekatan Kuantitatif, Kualitatif, Kombinasi, and R\&D. Penerbit CV. Alfabeta: Bandung.

33. Tang, G., Yu, B., Cooke, F. L., \& Chen, Y. 2017. High performance work system and kreativitas karyawan: The roles of perceived organisational support and devolved management. Personnel Review, 46 (7), 1318-1334.

34. Umukoro, J. E., \& Egwakhe, A. J. (2019). Job-Characteristics Dimensions and Employee Continuance Commitment. Global Journal of Management And Business Research.

35. McCaffery, L., \& Gibson, W. (1988). An Interview with William Gibson. Mississippi Review, 16(2/3), 217-236.

36. Tov, W. (2018). Well-being concepts and components.

37. Tsao, C. W., Chen, S. J., \& Wang, Y. H. (2016). Family governance oversight, performance, and high performance work systems. Journal of Business Research, 69(6), 2130-2137.

38. Wang, C. J., Tsai, H. T., \& Tsai, M. T. (2014). Linking transformational leadership and employee creativity in the hospitality industry: The influences of creative role identity, creative self-efficacy, and job complexity. Tourism Management, 40, 79-89.

39. Yukl, G. (2010). Kepemimpinan and Organisasi, diterjemahkan oleh Budi Suprianto. PT. Indeks Kelompok Gramedia. Jakarta.

40. Zheng, X., Zhu, W., Zhao, H., \& Zhang, C. (2015). Employee well being in organizations: Theoretical model, scale development, and cross cultural validation. Journal of Organizational Behavior, 36(5), 621-644.

41. Zhou, J., \& George, J. M. (2001). When job dissatisfaction leads to creativity: Encouraging the expression of voice. Academy of Management journal, 44(4), 682-696.

42. Zhou, J., \& Shalley, C. E. (2008). Expanding the scope and impact of organizational creativity research. Handbook of organizational creativity, 28(1), 125-147. 